\title{
Epidemiology of cyprinid herpesvirus-3 infection in latently infected carp from aquaculture
}

\author{
A. Baumer ${ }^{1}$, M. Fabian ${ }^{1}$, M. R. Wilkens ${ }^{2}$, D. Steinhagen ${ }^{1, *}$, M. Runge ${ }^{3, *, * *}$ \\ ${ }^{1}$ Fish Disease Research Unit, Centre of Infectious Diseases, University of Veterinary Medicine Hannover, Bünteweg 17, \\ 30559 Hannover, Germany \\ ${ }^{2}$ Department of Physiology, University of Veterinary Medicine Hannover, Bischofsholer Damm 15, 30173 Hannover, \\ Germany \\ ${ }^{3}$ Lower Saxony State Office for Consumer Protection and Food Safety, Food and Veterinary Institute Braunschweig/ \\ Hannover, Eintrachtweg 17, 30173 Hannover, Germany
}

\begin{abstract}
Cyprinid herpesvirus-3 (CyHV-3, koi herpesvirus, KHV) is the causative agent of an economically important disease in carp. The mode of transmission of this virus, especially how the infectious agent is introduced into ponds de novo, is not known in detail. The aim of this study was to investigate the shedding of CyHV-3 from fish with latent infections, under aquaculture conditions. Ponds in Saxony, Germany, with latently infected carp were examined at different times during the production cycle to investigate the influence of fish farming procedures on virus activation and shedding. Carp and water samples were investigated by quantitative real-time PCR. Some of the latently infected carp shed CyHV-3. Virus shedding was induced mainly when the ponds were drained and the carp either harvested or moved to different ponds, and was independent of the water temperature. This indicated that during these times there was a risk that effluent water from the ponds could disseminate the infectious agent. During summer, on-growing carp are infected with low numbers of CyHV-3. These findings are important for disease management strategies in carp aquaculture and for the design of testing protocols for the detection of latent infection in carp populations.
\end{abstract}

KEY WORDS: Cyprinid herpesvirus-3 - CyHV-3 - Koi herpesvirus - KHV - Transmission · Quantification · Real-time PCR Resale or republication not permitted without written consent of the publisher

\section{INTRODUCTION}

In the late 1990s, several studies described diseased koi carp Cyprinus carpio L. with the following previously unrecorded set of symptoms: necrosis of the gills, apathy, anorexia, dyspnoea, enophthalmus or exophthalmus and skin lesions (Ariav et al. 1999, Neukirch et al. 1999, Walster 1999, Hedrick et al. 2000, Perelberg et al. 2003). Shortly afterwards, a DNA virus subsequently designated as cyprinid herpesvirus-3 (CyHV-3) and also known as koi herpesvirus (KHV), was identified as the causative agent of this disease (Neukirch et al. 1999, Hedrick et al. 2000). The virus has been shown to be infective for ornamental carp varieties (koi) as well as for carp raised for human consumption (Bretzinger et al. 1999, Gilad et al. 2002, Waltzek et al. 2005). Today the disease associated with this infection, designated as koi herpesvirus disease (KHV-D), has a worldwide occurrence in aquaculture in populations of both carp varieties (Haenen \& Hedrick 2006). It has also been found in carp populations from natural waters, for instance in the Japanese Lake Biwa (Matsui et al. 2008, Minamoto et al. 2009a) and the Japanese river systems (Haramoto et al. 2007, Minamoto et al. 2009b). Due to that fact that clinical outbreaks may result in high morbidity and mortality (Walster 1999, Pikarsky et al. 2004), this virus can have a severe 
economic impact on fish breeders, retailers, and hobby fish owners (Perelberg et al. 2003). Therefore and because of its epizootic appearance, it has been designated as a notifiable disease in Germany (Bocklisch et al. 2006).

Although this disease and the pathogen have been well investigated since it was first described, little is known about its epidemiology, and in particular the mode of transmission within the pond aquaculture environment. Like other herpesviruses, CyHV-3 induces latent infections which can be reactivated several months after the initial exposure (St-Hilaire et al. 2005, Bergmann et al. 2009, Eide et al. 2011b). CyHV-3 has been detected in water samples from rivers and lakes with infected carp populations (Haramoto et al. 2007, 2009, Minamoto et al. 2009a,b, 2011). However, the infection dynamics, in particular the spreading of the virus within and between ponds, has not been studied in detail.

In European traditional carp farming, carp are stocked in natural on-growing ponds over summer, and harvested from the ponds in autumn. Over winter, carp are kept in deeper winter ponds, which are harvested in spring. Subsequently, these carp are stocked in production ponds for an additional growth period (Billard 1999). The necessary draining of ponds during the harvesting process in autumn and spring could be regarded as an additional stressor for carp, and therefore could intensify virus production and release from infected individuals. A controlled study involving the exposure of carp to water samples from ponds stocked with latently infected carp has not been performed so far.

The present study reports data on the CyHV-3 load in carp, water and plankton specimens sampled from aquaculture ponds in Saxony, Germany, at different time points during the production process of carp farming. With CyHV-3 loads determined by means of a quantitative real-time PCR (qPCR) (Gilad et al. 2004), these results yielded insights into CyHV-3 epidemiology in European carp pond aquaculture.

\section{MATERIALS AND METHODS}

\section{Field study}

Fish samples. Farmed common carp were sampled from 8 ponds in carp farms in Saxony, Germany, between 2007 and 2010. The ponds were stocked with popu- lations which had experienced a clinical outbreak of CyHV-3 disease associated with morbidity and mortality from 2007 until 2009, i.e. between 3 and 21 mo prior to sampling (Table 1). The age of sampled carp ranged from juveniles after their first summer $(\mathrm{C} 1$, average weight $50 \mathrm{~g}$ ) to $3 \mathrm{yr}$ old carp (C3) with an average body weight of $1500 \mathrm{~g}$. Sampling of the carp (Table 2) was performed between 1 and 5 times a year. One to 10 individuals were taken from each pond and samples from gill, liver, kidney, spleen, and brain were collected. Tissues from each individual carp were pooled, homogenised, and an aliquot of $25 \mathrm{mg}$ was taken and investigated for the occurrence of CyHV-3 by qPCR.

Water samples. In addition to carp, samples from the water column and the adjoining drainage ditch were collected from each pond to test for the presence of CyHV-3. Water temperature was also measured at the time of sampling.

For the detection of CyHV-3, a $100 \mathrm{ml}$ aliquot was taken from each water sample, $\mathrm{Mg}^{2+}$ was added as a cation and then the sample was passed through an electronegative filter system ( 0.45 pore size, Millipore) according to the method described by Katayama et al. (2002) and Haramoto et al. (2009). A final concentration of the virus was performed by microfiltration (Centriprep YM-50, Millipore). For this, $3 \times 5 \mathrm{ml}$ of the eluates of the first filtration step were centrifuged for $5 \mathrm{~min}$ at $1500 \times \mathrm{g}$. The received concentrate $(550 \mu \mathrm{l})$ was used for the detection of CyHV-3 by qPCR.

Plankton samples. Additionally, plankton samples were collected from several ponds. For plankton collection, a 201 water sample was collected from each pond and passed through a $200 \mu \mathrm{m}$ mesh followed by a $63 \mu \mathrm{m}$ mesh (Retsch). Plankton samples were

Table 1. Field study: Age of carp, clinical disease and sampling periods. C1: Carp after their first summer (juveniles) approx. 50 g; C2: Carp after their second summer, approx. $250 \mathrm{~g}$; C3: Carp after their third summer, approx. $1500 \mathrm{~g}$

\begin{tabular}{|c|c|c|c|}
\hline $\begin{array}{l}\text { Pond } \\
\text { ID }\end{array}$ & $\begin{array}{c}\text { Age of } \\
\text { stocked carp }\end{array}$ & $\begin{array}{l}\text { Clinical outbreak } \\
\text { of CyHV-3 disease }\end{array}$ & Sampling period \\
\hline 0 & C3 & Summer 2007 & Autumn 2008 \\
\hline 1 & $\mathrm{C} 2$ & Summer 2007 & Autumn 2007-summer 2009 \\
\hline 2 & $\mathrm{C} 1$ & Summer 2008 & Spring 2009-spring 2010 \\
\hline 3 & $\mathrm{C} 1$ & Summer 2008 & Autumn 2009-spring 2010 \\
\hline 4 & $\mathrm{C} 2$ & Summer 2008 & Autumn 2009-spring 2010 \\
\hline 7 & $\mathrm{C} 1$ & Summer 2009 & Autumn 2009-spring 2010 \\
\hline 8 & $\mathrm{C} 1$ & Summer 2009 & Autumn 2009-spring 2010 \\
\hline 9 & C3 & Summer 2009 & Autumn 2009 \\
\hline
\end{tabular}


Table 2. Overview of carp production cycle in traditional European pond aquaculture, CyHV-3 disease outbreak and sampling

\begin{tabular}{|c|c|c|c|c|}
\hline Time & Season & $\begin{array}{l}\text { Carp production } \\
\text { cycle }\end{array}$ & $\begin{array}{l}\text { Clinical outbreak of } \mathrm{CyHV}-3 \\
\text { disease in pond }\end{array}$ & $\begin{array}{l}\text { Sampling } \\
\text { of ponds }\end{array}$ \\
\hline \multirow[t]{3}{*}{ Year 1} & Early summer & Spawning & - & - \\
\hline & Summer & $\begin{array}{l}\text { On-growing of carp fry to first } \\
\text { year (C1) carp }\end{array}$ & Ponds 2, 3, 7, 9 & - \\
\hline & Autumn & $\begin{array}{l}\text { Harvesting of C1 carp, stocking } \\
\text { to winter ponds }\end{array}$ & - & Ponds 3, 7, 8 \\
\hline \multirow[t]{3}{*}{ Year 2} & Spring & $\begin{array}{l}\text { Harvesting of C1 carp from winter ponds, } \\
\text { stocking to production ponds }\end{array}$ & $s$, & Ponds $2,3,7,8$ \\
\hline & Summer & $\begin{array}{l}\text { On-growing of C1 carp to second year } \\
\text { (C2) carp }\end{array}$ & Ponds 1,4 & Pond 2 \\
\hline & Autumn & $\begin{array}{l}\text { Harvesting of C2 carp, stocking to } \\
\text { winter ponds }\end{array}$ & - & Ponds 1, 2, 4 \\
\hline \multirow[t]{3}{*}{ Year 3} & Spring & $\begin{array}{l}\text { Harvesting of C } 2 \text { carp from winter ponds, } \\
\text { stocking to production ponds }\end{array}$ & s, & Ponds $1,2,4$ \\
\hline & Summer & $\begin{array}{l}\text { On-growing of C2 carp to third year } \\
\text { (C3) carp }\end{array}$ & Ponds 0,9 & $\begin{array}{l}\text { Pond } 1 \\
\text { (2 time points) }\end{array}$ \\
\hline & Autumn & Harvesting of C3 carp, marketing & - & Ponds 0,9 \\
\hline
\end{tabular}

washed with PBS twice, centrifuged (5 min at $250 \times$ $g)$, and the pellet was re-suspended in $100 \mu \mathrm{l}$ distilled water.

\section{Exposure of sentinel carp}

Recipient carp (15 g, 6 to $9 \mathrm{mo}$ ) originated from a laboratory stock of a single crossing $(\mathrm{R} 8 \times \mathrm{R} 3)$ and were obtained as fertilised eggs from De Haar Vissen, University of Wageningen, The Netherlands. In the laboratory, the carp were raised in recirculating tap water at 20 to $23^{\circ} \mathrm{C}$ under virusand parasite-free conditions. Before exposure to pond water, the absence of a CyHV-3 infection was confirmed by analysing 6 carp from the stock for the presence of CyHV-3-specific DNA sequences by qPCR. In addition, the susceptibility of these carp to an infection with CyHV-3 was confirmed by immersing 6 carp into a bath containing 250 TCID $_{50} \mathrm{ml}^{-1}$ tissue culture-derived CyHV-3 (strain CyHV-3-I, obtained from the FriedrichLoeffler-Institut, Germany). All 6 carp exposed to CyHV-3-I developed clinical signs of disease, died within $10 \mathrm{~d}$ and were found to be positive for the virus by qPCR analysis.

During the field study, 201 of effluent water was collected from each pond and 6 recipient carp from the virus-free laboratory stock were placed into this water sample at the pond site. The recipient carp were kept at an ambient temperature overnight, transported to the laboratory, placed into disinfected glass tanks and subsequently heated to $23^{\circ} \mathrm{C}$ within $24 \mathrm{~h}$. The carp were monitored daily for clinical signs of CyHV-3-associated disease and were euthanised after 14 d. Samples from gill, liver, kidney, spleen, and brain were collected and also investigated for the occurrence of CyHV-3-specific DNA sequences with qPCR.

\section{Molecular biological techniques}

DNA extraction. DNA was extracted from $25 \mathrm{mg}$ tissue samples, from $100 \mu \mathrm{l}$ concentrated water samples or from plankton samples with the QIAamp ${ }^{\circledR}$ DNA Mini-Kit (Qiagen) according to the manufacturer's instructions.

Cloning of CyHV-3 DNA targets into a plasmid vector and standard curve construction. A recombinant plasmid-based virus genome copy quantification was performed using the PCR product amplified with the primers KHV-86F and KHV-163R (Gilad et al. 2004). The amplicon was ligated into the pGEM ${ }^{\circledR}$. $\mathrm{T}$ Easy Vector System II (Promega) and propagated in Escherichia coli cells (Solopack ${ }^{\circledR}$ Gold Competent Cells, Stratagene Europe). Plasmids were isolated with the PureYieldTM Plasmid MiniPrep System (Promega) and a standard curve was prepared ranging from 1 to $10^{8}$ copies per $5 \mu$ for quantification of 
the copy numbers from each sample. The standard curve was calculated with the MxPro QPCR Software, version V 4.10 (Agilent Technologies). PCR runs were accepted when the standard curve correlation co-efficient was $>0.99$.

Quantitative real-time PCR for detection of CyHV-3. The PCR for detection of CyHV-3 was based on a method originally described by Gilad et al. (2004). The final reaction mix of $25 \mu$ l contained $2 \mu$ of a solution of the KHV_86F and KHV_163R primers (final concentration of each primer: $0.8 \mu \mathrm{M}$ ) and of the KHV_109P probe labelled with FAM and BHQ1 (final concentration: $0.1 \mu \mathrm{M}$ ), $12.5 \mu \mathrm{l}$ of the QuantiTect ${ }^{\circledR}$ Multiplex PCR Kit solution (Qiagen), $3.25 \mu \mathrm{l}$ distilled water and $5 \mu \mathrm{l}$ of extracted DNA as a template. As an internal control (IC), $0.25 \mu \mathrm{l}\left(5 \times 10^{4} \mathrm{~mol}-\right.$ ecules) of a plasmid containing the sequence of the enhanced green fluorescent protein (EGFP) gene was included in each reaction. This was detected with $2 \mu$ l of a solution containing EGFP-1 forward and EGFP-10 reverse primers (final concentration of each primer: $0.2 \mu \mathrm{M}$ ) and EGFP1 probe labelled with HEX and BHQ1 (final concentration: $0.12 \mu \mathrm{M}$ ) (Hoffmann et al. 2006). The results of the PCR were accepted when the threshold cycle value $\left(C_{\mathrm{T}}\right)$ of the IC was <28. In our investigations, amplification and quantification of target DNA were performed with an Mx3005P ${ }^{\text {TM }}$ instrument (Agilent Technologies). After initial denaturation at $95^{\circ} \mathrm{C}$ for $15 \mathrm{~min}, 42$ cycles were performed with denaturation at $95^{\circ} \mathrm{C}$ for $1 \mathrm{~min}$, primer annealing at $60^{\circ} \mathrm{C}$ for $30 \mathrm{~s}$ and elongation at $70^{\circ} \mathrm{C}$ for $30 \mathrm{~s}$. Negative controls to identify DNA carryover and positive controls were included in each PCR run. A tissue sample from an uninfected koi was carried through the DNA extraction procedure as a negative control. Additionally, distilled water was used as a no-template control in the PCR. A tissue sample from koi infected with CyHV-3 was used as positive control.

Cloned targets with a known number of copies were included in each PCR run to generate a standard curve as described above.

\section{RESULTS}

\section{Detection of CyHV-3 in the tissues of carp from aquaculture ponds and evaluation of viral load}

Overall prevalence. All carp appeared clinically healthy upon sampling. In all ponds, with the exception of Pond 0, CyHV-3-positive carp could be detected, but not every individual carp was positive.

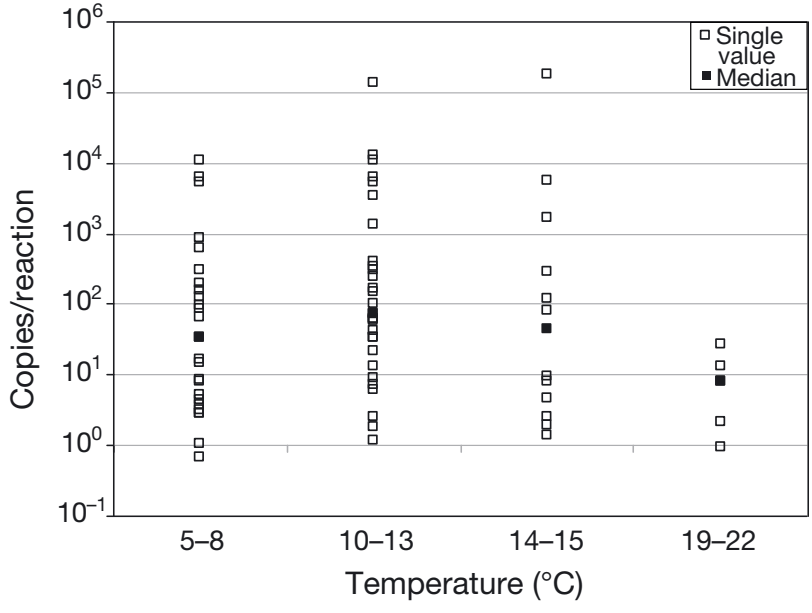

Fig. 1. Quantitative detection of CyHV-3 specific DNA in samples of latently infected common carp Cyprinus carpio obtained from aquaculture ponds, at 4 different temperature ranges

The rate of detection ranged from 8 out of 38 individuals in Pond 1 to 11 out of 11 individuals in Pond 4 (Table 3 ). The virus load in carp positive for CyHV-3 ranged from $<10$ up to $2 \times 10^{5}$ copies per reaction (Fig. 1). With the method applied, at least 10 copies of the CyHV-3 genome could be detected reproducibly.

Seasonality and water temperature. CyHV-3-specific DNA was found in every sample taken in each season with the exception of a summer sampling from Pond 2 and autumn sampling in Pond 0 (Tables 3 \& 4). In samples taken at low water temperatures of 5 to $8^{\circ} \mathrm{C}, 25$ out of 60 carp individuals were found to be positive for $\mathrm{CyHV}-3$; at 10 to $13^{\circ} \mathrm{C}, 29$ out of 61 carp and at 14 to $15^{\circ} \mathrm{C}, 12$ out of 20 carp were positive for CyHV-3-specific DNA sequences. However, at summer temperatures of 19 to $22^{\circ} \mathrm{C}$, just 5 individuals out of 37 carp examined were found to be positive for CyHV-3 by PCR (Table 4).

Age classes. CyHV-3 infection was detected in all age classes, from carp juveniles of the year (C1) up to carp after the third summer (C3). From 109 examined C1 carp, 45 individuals were found to be positive for CyHV-3, 19 individuals were positive from 49 carp collected after the second summer (C2) and CyHV-3specific DNA sequences could be detected in 7 out of 20 C3 carp (data not shown).

Virus load. The number of CyHV-3 copies within the samples obtained from farmed carp ranged from $<10$ to $1 \times 10^{4}$ at temperatures from 5 to $8^{\circ} \mathrm{C}$, from $<10$ to $2 \times 10^{5}$ at 10 to $15^{\circ} \mathrm{C}$, and $<10$ to $3 \times 10^{1}$ at 19 to $22^{\circ} \mathrm{C}$. Samples with the highest number of virus copies were detected in carp collected from ponds at a water temperature in the range of 5 to $15^{\circ} \mathrm{C}$. These 
Table 3. Detection of CyHV-3 DNA in samples from common carp, water and plankton obtained from aquaculture ponds stocked with carp carrying a latent infection with CyHV-3 and in sentinel carp exposed to draining water from the examined ponds. +: CyHV-3-PCR positive; -: CyHV-3-PCR negative; n.t.: not tested

\begin{tabular}{|c|c|c|c|c|c|c|c|c|c|c|}
\hline \multirow{2}{*}{$\begin{array}{l}\text { Pond } \\
\text { ID }\end{array}$} & \multirow{2}{*}{$\begin{array}{l}\text { Season of } \\
\text { sampling }\end{array}$} & \multicolumn{3}{|c|}{ Farmed carp } & \multicolumn{3}{|c|}{ Exposed SPF carp } & \multirow{2}{*}{$\begin{array}{c}\text { Water from } \\
\text { fish pond } \\
\text { (1 sample each) }\end{array}$} & \multirow{2}{*}{$\begin{array}{c}\text { Draining } \\
\text { water } \\
\text { (1 sample each) }\end{array}$} & \multirow{2}{*}{$\begin{array}{c}\text { Plankton } \\
\text { (1 sample } \\
\text { each) }\end{array}$} \\
\hline & & $\mathrm{n}$ & $\begin{array}{l}\text { PCR } \\
\text { +ve }\end{array}$ & $\begin{array}{l}\text { PCR } \\
\text {-ve }\end{array}$ & $\mathrm{n}$ & $\begin{array}{l}\text { PCR } \\
\text { +ve }\end{array}$ & $\begin{array}{l}\text { PCR } \\
\text {-ve }\end{array}$ & & & \\
\hline \multirow[t]{2}{*}{0} & Autumn & 10 & 0 & 10 & 6 & 0 & 6 & + & - & - \\
\hline & Total & 10 & 0 & 10 & 6 & 0 & 6 & 1 & 0 & 0 \\
\hline \multirow[t]{5}{*}{1} & Autumn & 10 & 3 & 7 & 6 & 1 & 5 & - & - & - \\
\hline & Spring & 10 & 3 & 7 & 6 & 0 & 6 & - & - & n.t. \\
\hline & Early summer & 8 & 1 & 7 & 6 & 0 & 6 & - & - & n.t. \\
\hline & Summer & 10 & 1 & 9 & 6 & 0 & 6 & - & - & n.t. \\
\hline & Total & 38 & 8 & 30 & 24 & 1 & 23 & 0 & 0 & 0 \\
\hline \multirow[t]{6}{*}{2} & Spring & 10 & 2 & 8 & 6 & 0 & 6 & - & - & n.t. \\
\hline & Early summer & 10 & 3 & 7 & 6 & 0 & 6 & - & - & n.t. \\
\hline & Summer & 9 & 0 & 9 & 6 & 0 & 6 & - & - & n.t. \\
\hline & Autumn & 10 & 5 & 5 & 6 & 0 & 6 & - & - & - \\
\hline & Spring & 10 & 2 & 8 & 6 & 0 & 6 & - & - & n.t. \\
\hline & Total & 49 & 12 & 37 & 30 & 0 & 30 & 0 & 0 & 0 \\
\hline \multirow[t]{3}{*}{3} & Autumn & 10 & 5 & 5 & 6 & 1 & 5 & - & - & - \\
\hline & Spring & 10 & 4 & 6 & 6 & 0 & 6 & + & - & n.t. \\
\hline & Total & 20 & 9 & 11 & 12 & 1 & 11 & 1 & 0 & 0 \\
\hline \multirow[t]{3}{*}{4} & Autumn & 10 & 10 & 0 & 6 & 2 & 4 & - & - & - \\
\hline & Spring & 1 & 1 & 0 & 6 & 0 & 6 & + & - & n.t. \\
\hline & Total & 11 & 11 & 0 & 12 & 2 & 10 & 1 & 0 & 0 \\
\hline \multirow[t]{3}{*}{7} & Autumn & 10 & 10 & 0 & 6 & 0 & 6 & - & - & - \\
\hline & Spring & 10 & 4 & 6 & 6 & 0 & 6 & - & - & n.t. \\
\hline & Total & 20 & 14 & 6 & 12 & 0 & 12 & 0 & 0 & 0 \\
\hline \multirow[t]{3}{*}{8} & Autumn & 10 & 5 & 5 & 6 & 0 & 6 & + & - & + \\
\hline & Spring & 10 & 5 & 5 & 6 & 0 & 6 & - & - & n.t. \\
\hline & Total & 20 & 10 & 10 & 12 & 0 & 12 & 1 & 0 & 1 \\
\hline \multirow[t]{2}{*}{9} & Autumn & 10 & 7 & 3 & 6 & 0 & 6 & - & - & n.t. \\
\hline & Total & 10 & 7 & 3 & 6 & 0 & 6 & 0 & 0 & \\
\hline
\end{tabular}

carp were all sampled during a period of pond draining for harvesting (Table 4, Fig. 1). An influence of carp age or time between the clinical outbreak of CyHV-3 disease and virus load at the time of sampling could not be detected.

\section{Detection of CyHV-3 in pond water}

When recipient carp were kept in the effluent water from ponds stocked with latently infected carp, only a single individual acquired an infection with CyHV-3. Signs of clinical disease or mortality were not observed in these experiments. One out of 6 specific pathogen-free (SPF) carp kept in a sample of draining water from Ponds 1 and 3, and 2 out of 6 SPF carp kept in draining water from Pond 4 tested CyHV-3 positive (Table 3). Interestingly, when the corresponding water samples which were taken directly from the pond or from the draining channels were analysed using the virus concentration method, CyHV-3 could not be detected, even though sentinel carp exposed to this water later tested positive for the presence of CyHV-3. However, using the virus concentration method, CyHV-3 was detected in additional water samples taken from Ponds 0, 3, 4 and 8. At the same time, a corresponding plankton sample collected from Pond 8 tested positive for CyHV-3 (Tables 3 \& 4).

\section{DISCUSSION}

In the present study, the detection of CyHV-3 in tissues from carp sampled from distinct ponds differed widely. Whereas in some ponds only about a quarter of the fish contained detectable amounts of the pathogen, in other ponds half, or in one pond even all carp investigated were found to be CyHV-3 positive. The load of CyHV-3 in these latently infected carp 
Table 4. Detection of CyHV-3-specific DNA in samples from common carp, water and plankton obtained from aquaculture ponds holding carp with a latent CyHV-3 infection compared to water temperature. Values are numbers of CyHV-3-positive individuals, water and plankton samples/total amount of individuals and water samples investigated. In parentheses: maximum/minimum amount of $\mathrm{CyHV}-3$ genome equivalent. n.t.: not tested

\begin{tabular}{|c|c|c|c|c|c|c|}
\hline $\begin{array}{l}\text { Water } \\
\text { temp. }\left({ }^{\circ} \mathrm{C}\right)\end{array}$ & $\begin{array}{l}\text { Farmed } \\
\text { carp }\end{array}$ & $\begin{array}{l}\text { SPF carp kept in } \\
201 \text { draining water }\end{array}$ & $\begin{array}{l}\text { Water from } \\
\text { fish pond }\end{array}$ & $\begin{array}{l}\text { Draining } \\
\text { water }\end{array}$ & Plankton & $\begin{array}{l}\text { Pond } \\
\text { ID }\end{array}$ \\
\hline Range 5-8 & $25 / 60$ & $0 / 36$ & $2 / 6$ & $0 / 6$ & $1 / 4$ & \\
\hline 5 & $5 / 10\left(<10 / 6 \times 10^{3}\right)$ & $0 / 6$ & $1 / 1(<10)$ & $0 / 1$ & $1 / 1(<10)$ & 8 \\
\hline 6 & $5 / 10\left(<10 / 2 \times 10^{1}\right)$ & $0 / 6$ & $0 / 1$ & $0 / 1$ & $0 / 1$ & 2 \\
\hline 6 & $10 / 10\left(<10 / 1 \times 10^{4}\right)$ & $0 / 6$ & $0 / 1$ & $0 / 1$ & $0 / 1$ & 7 \\
\hline 6 & $3 / 10\left(<10 / 1 \times 10^{1}\right)$ & $0 / 6$ & $0 / 1$ & $0 / 1$ & n.t. & 1 \\
\hline 6 & $0 / 10$ & $0 / 6$ & $1 / 1(<10)$ & $0 / 1$ & $0 / 1$ & 0 \\
\hline 8 & $2 / 10 \quad(<10)$ & $0 / 6$ & $0 / 1$ & $0 / 1$ & n.t. & 2 \\
\hline Range 10-13 & $29 / 61$ & $4 / 42$ & $2 / 7$ & $0 / 7$ & $0 / 3$ & \\
\hline 10 & $4 / 10\left(6 \times 10^{1} / 1 \times 10^{4}\right)$ & $0 / 6$ & $1 / 1(<10)$ & $0 / 1$ & n.t. & 3 \\
\hline 10 & $2 / 10\left(6 \times 10^{1} / 2 \times 10^{2}\right)$ & $0 / 6$ & $0 / 1$ & $0 / 1$ & n.t. & 2 \\
\hline 10 & $1 / 1 \quad(<10)$ & $0 / 6$ & $1 / 1(<10)$ & $0 / 1$ & n.t. & 4 \\
\hline 12 & $4 / 10\left(<10 / 2 \times 10^{1}\right)$ & $0 / 6$ & $0 / 1$ & $0 / 1$ & n.t. & 7 \\
\hline 12 & $3 / 10 \quad\left(<10 / 6 \times 10^{3}\right)$ & $1 / 6\left(6 \times 10^{2}\right)$ & $0 / 1$ & $0 / 1$ & $0 / 1$ & 1 \\
\hline 13 & $5 / 10\left(4 \times 10^{1} / 2 \times 10^{5}\right)$ & $1 / 6(<10)$ & $0 / 1$ & $0 / 1$ & $0 / 1$ & 3 \\
\hline 13 & $10 / 10\left(<10 / 4 \times 10^{2}\right)$ & $2 / 6 \quad(<10)$ & $0 / 1$ & $0 / 1$ & $0 / 1$ & 4 \\
\hline Range $14-15$ & $12 / 20$ & $0 / 12$ & $0 / 2$ & $0 / 2$ & n.t. & \\
\hline 14 & $7 / 10\left(<10 / 2 \times 10^{3}\right)$ & $0 / 6$ & $0 / 1$ & $0 / 1$ & n.t. & 9 \\
\hline 15 & $5 / 10\left(<10 / 2 \times 10^{5}\right)$ & $0 / 6$ & $0 / 1$ & $0 / 1$ & n.t. & 8 \\
\hline Range 19-22 & $5 / 37$ & $0 / 24$ & $0 / 4$ & $0 / 4$ & n.t. & \\
\hline 19 & $1 / 10 \quad(<10)$ & $0 / 6$ & $0 / 1$ & $0 / 1$ & n.t. & 1 \\
\hline 19.5 & $3 / 10\left(<10 / 3 \times 10^{1}\right)$ & $0 / 6$ & $0 / 1$ & $0 / 1$ & n.t. & 2 \\
\hline 19.5 & $1 / 8 \quad(<10)$ & $0 / 6$ & $0 / 1$ & $0 / 1$ & n.t. & 1 \\
\hline 22 & $0 / 9$ & $0 / 6$ & $0 / 1$ & $0 / 1$ & n.t. & 2 \\
\hline
\end{tabular}

varied over a wide range. While a large proportion of carp harboured low virus loads of between less than 10 and 30 copy numbers, in samples from several individuals, virus loads of $10^{3}$ up to $10^{5}$ copies per reaction were measured. In experimental (Gilad et al. 2004) and field studies (Cornwell et al. 2012) with latently infected carp, low virus loads of between 1 and 800 genome copies were recorded. The higher number of genome copies found in the present study might indicate a recrudescence of the infection in some carp. However, clinical signs of the disease associated with CyHV-3 infection were not observed in any of the carp collected. The re-activation of CyHV-3 was not related to carp age: High copy numbers were found in individuals from all 3 age groups examined, despite low ambient water temperature. In the temperature range of 19 to $22^{\circ} \mathrm{C}$, in which most clinical outbreaks of the disease have been observed (Hedrick et al. 2005, St-Hilaire et al. 2005), the virus load in tissues of latently infected carp was low and ranged between less than 10 and 30 copies. In tissue samples from carp collected at 5 to $8^{\circ} \mathrm{C}, 10$ to $13^{\circ} \mathrm{C}$ or 14 to $15^{\circ} \mathrm{C}$, the range of the viral load was much wider and reached $10^{4}$ to $10^{5}$ copies per reaction. No significant differences in virus load could be detected in the tissues of carp sampled between 5 and $15^{\circ} \mathrm{C}$.

In an experimental study, re-activation of the virus was observed when CyHV-3-infected carp were transferred from 12 to $21^{\circ} \mathrm{C}$ (St-Hilaire et al. 2005). In the current investigation, individuals with a high virus load were found in particular in carp populations sampled during the harvesting of ponds in spring or autumn when the water temperature was lower. During the harvesting process, the water level of the ponds is lowered over a period of several days and the fish gather in shallow water near the outlet of the pond under crowded and hypoxic conditions (Billard 1999) which could be stressors for the carp. This situation might have induced a reactivation of a latent CyHV-3 infection in the carp, as has been observed by Bergmann \& Kempter (2011) in response to netting stress. In the experiments described by Bergmann \& Kempter (2011), the virus load increased to $10^{3}$ copies in individual carp 3 to $7 \mathrm{~d}$ after a stress event at a water temperature of $20^{\circ} \mathrm{C}$. In a carp population from the Japanese Lake Biwa, high CyHV-3 concentrations were primarily detected during reproduction in the spring (Uchii et al. 2010). 
Then a high virus load coincided with a high testosterone level in the carp population, which has been reported to suppress immune functions in common carp (cited from Uchii et al. 2010). In the current study, the stress response to the harvesting process could not be investigated. Non-stressed carp can be captured from a natural pond after they have been baited with feed. At low water temperatures in the spring or autumn, carp do not respond well to baiting with feed, and therefore sampling of non-stressed carp before harvesting from the natural ponds, which would be needed for proof of this hypothesis, was not feasible.

Our data indicate that carp kept at low temperatures can also carry high virus loads and that a CyHV-3 infection can most likely be reactivated from latency even at a water temperature as low as 5 to $8^{\circ} \mathrm{C}$. The wide range of less than 10 to more than $10^{5}$ virus copies, which was found in the tissues of carp sampled during the harvesting process, might reflect different kinetics of virus reactivation and excretion, as observed by Bergmann \& Kempter (2011) in individual carp after a stress event. In carp with a latent CyHV-3 infection, the virus is present in many cases in very low copy numbers (Bigarré et al. 2009, Bergmann et al. 2010, Eide et al. 2011a), which are often not detectable with the diagnostic methods used. It has to be assumed that individual carp in our study that were found to be negative for the virus could still be virus carriers. These findings, however, emphasise the importance of sampling an adequate number of individuals when determining the infection status of a carp population.

CyHV-3 could also be detected in pond water, in particular on sampling dates during the harvesting period when individuals with high copy numbers of the virus were found among the carp population. In some samples, the virus could then be demonstrated directly in the water, while on some sampling dates, the pond water was infective for recipient carp. This suggests that the effluent water produced during harvesting might contribute to the transmission of the infection. Overall, CyHV-3 could be detected in 7 out of 19 samples of pond water, either directly by PCR after applying a method for virus enrichment or by the exposure of sentinel carp to pond water. Virus concentration in the water samples, however, were at the detection limits of the applied methods. This could explain why CyHV-3 was not found by PCR in samples which were infective for sentinel carp.

The presence of CyHV-3 in water samples was not related to temperature. In our study the virus was detected in water samples from ponds even at 5 to $10^{\circ} \mathrm{C}$, and transmission of CyHV-3 to recipient carp occurred in samples taken at 12 or $13^{\circ} \mathrm{C}$. In a Japanese river, CyHV-3 was present at a temperature of 9 to $11^{\circ} \mathrm{C}, 4$ mo before carp suffered from an outbreak of a clinical infection with CyHV-3 in same the river (Haramoto et al. 2007). This indicates that excretion of CyHV-3, and most likely reactivation in latently infected carp, can occur at low water temperature as well.

Taken together, the current investigation shows that in traditional European carp-farming systems, CyHV-3 infection is reactivated mainly during harvesting procedures in the spring and autumn. When carp are exposed to crowding in shallow water, individuals that carry high virus loads may excrete virus into effluent water which may serve as a source of infection. To the best of our knowledge, the present communication presents for the first time quantitative data on virus load of individual carp from the pond environment, and emphasises the fact that a high virus load can be found in individual carp over a wide range of temperatures from 5 to $15^{\circ} \mathrm{C}$. In addition, the investigation also showed high variability in the virus load of individual carp with a high percentage of individuals in which the virus could not be detected. Factors which influence virus reactivation and virus load still need to be clarified. However, it can be concluded from the data that virus reactivation occurs during harvesting of carp from production ponds as well as from winter ponds, when CyHV-3 can be found in effluent water. Transmission of the virus to recipient carp by effluent water occurred even at 12 and $13^{\circ} \mathrm{C}_{i}$ thus, it can be concluded that effluent water from the harvesting process can be a risk for transmission of the pathogen.

Acknowledgements. This study was conducted with support from the Saxon State Ministry of Environment and Agriculture and the Saxon Animal Diseases Fund. The data of this manuscript partly formed the basis of a doctoral thesis accepted by the University of Veterinary Medicine Hannover on February 9, 2011. The authors acknowledge support given by K. Böttcher, G. Bräuer and G. Füllner and financial support by the European Fisheries Fund according to regulation (EG) 1198/2006.

\section{LITERATURE CITED}

Ariav R, Tinman S, Bejerano I (1999) First report of a newly emerging viral disease of Cyprinus carpio species in Israel. Proc 9th Int Conf Dis Fish Shellfish, 19-24 September, Rhodes, Greece, p 151

Bergmann SM, Kempter J (2011) Detection of koi herpesvirus (KHV) after re-activation in persistently infected common carp (Cyprinus carpio L.) using non- 
lethal sampling methods. Bull Eur Assoc Fish Pathol 31: 92-100

Bergmann SM, Schutze H, Fischer U, Fichtner D and others (2009) Detection of koi herpes-virus (KHV) genome in apparently healthy fish. Bull Eur Assoc Fish Pathol 29: 145-152

Bergmann SM, Riechardt M, Fichtner D, Lee P, Kempter J (2010) Investigation on the diagnostic sensitivity of molecular tools used for detection of koi herpesvirus. J Virol Methods 163:229-233

Bigarré L, Baud M, Cabon J, Antychowicz J and others (2009) Differentiation between Cyprinid herpesvirus type-3 lineages using duplex PCR. J Virol Methods 158: 51-57

Billard R (ed) (1999) Carp: biology and culture. Springer Praxis, Chichester

Bocklisch H, Landsiedel U, Dresenkamp B (2006) Ausbruch der Koi-Herpesvirusinfektion in einer großen Teichwirtschaft in Nordthüringen. Tierarztl Prax 34:121-125

Bretzinger A, Fischer-Scherl T, Oumouna M, Hoffmann R, Truyen U (1999) Mass mortalities in koi carp, Cyprinus carpio, associated with gill and skin disease. Bull Eur Assoc Fish Pathol 19:182-185

Cornwell ER, Anderson GB, Wooster GA, Getchell RG and others (2012) Low prevalence of cyprinid herpesvirus 3 found in common carp (Cyprinus carpio carpio) collected from nine locations in the Great Lakes. J Wildl Dis 48: 1092-1096

Eide K, Miller-Morgan T, Heidel J, Bildfell R, Jin L (2011a) Results of total DNA measurement in koi tissue by Koi Herpes Virus real-time PCR. J Virol Methods 172:81-84

Eide KE, Miller-Morgan T, Heidel JR, Kent ML and others (2011b) Investigation of koi herpesvirus latency in koi. J Virol 85:4954-4962

Gilad O, Yun S, Andree KB, Adkison MA and others (2002) Initial characteristics of koi herpesvirus and development of a polymerase chain reaction assay to detect the virus in koi, Cyprinus carpio koi. Dis Aquat Org 48: 101-108

Gilad O, Yun S, Zagmutt-Vergara FJ, Leutenegger CM, Bercovier H, Hedrick RP (2004) Concentrations of a Koi herpesvirus (KHV) in tissues of experimentally infected Cyprinus carpio koi as assessed by real-time TaqMan PCR. Dis Aquat Org 60:179-187

Haenen O, Hedrick R (2006) Koi herpesvirus workshop. Bull Eur Assoc Fish Pathol 26:26-37

Haramoto E, Kitajima M, Katayama H, Ohgaki S (2007) Detection of koi herpesvirus DNA in river water in Japan. J Fish Dis 30:59-61

Haramoto E, Kitajima M, Katayama H, Ito T, Ohgaki S (2009) Development of virus concentration methods for detection of koi herpesvirus in water. J Fish Dis 32:297-300

Hedrick RP, Gilad O, Yun S, Spnagenberg JV and others (2000) A herpesvirus associated with mass mortality of

Editorial responsibility: V. Gregory Chinchar, Jackson, Mississippi, USA juvenile and adult koi, a strain of common carp. J Aquat Anim Health 12:44-57

Hedrick R, Gilad O, Yun S, McDowell TS, Waltzek TB, Kelley GO, Adkison MA (2005) Initial isolation and characterization of a herpes-like virus (KHV) from koi and common carp. Bull Eur Assoc Fish Pathol 2:1-7

Hoffmann B, Depner K, Schirrmeier H, Beer M (2006) A universal heterologous internal control system for duplex real-time RT-PCR assays used in a detection system for pestiviruses. J Virol Methods 136:200-209

Katayama H, Shimasaki A, Ohgaki S (2002) Development of a virus concentration method and its application to detection of enterovirus and Norwalk virus from coastal seawater. Appl Environ Microbiol 68:1033-1039

- Matsui K, Honjo M, Kohmatsu Y, Uchii K, Yonekura R, Kawabata Z (2008) Detection and significance of koi herpesvirus (KHV) in freshwater environments. Freshw Biol 53:1262-1272

> Minamoto T, Honjo MN, Kawabata Z (2009a) Seasonal distribution of cyprinid herpesvirus 3 in Lake Biwa, Japan. Appl Environ Microbiol 75:6900-6904

- Minamoto T, Honjo MN, Uchii K, Yamanaka H and others (2009b) Detection of cyprinid herpesvirus 3 DNA in river water during and after an outbreak. Vet Microbiol 135: 261-266

Minamoto T, Honjo MN, Yamanaka H, Tanaka N, Itayama T, Kawabata Z (2011) Detection of cyprinid herpesvirus3 DNA in lake plankton. Res Vet Sci 90:530-532

Neukirch M, Böttcher K, Bunnajirakul S (1999) Isolation of a virus from koi with altered gills. Bull Eur Assoc Fish Pathol 19:221-222

Perelberg A, Smirnov M, Hutoran M, Diamant A, Bejerano Y, Kotler M (2003) Epidemiological description of a new viral disease afflicting cultured Cyprinus carpio in Israel. Isr J Aquac Bamidgeh 55:5-12

Pikarsky E, Ronen A, Abramowitz J, Levavi-Sivan B and others (2004) Pathogenesis of acute viral disease induced in fish by carp interstitial nephritis and gill necrosis virus. J Virol 78:9544-9551

St-Hilaire S, Beevers N, Way K, Le Deuff RM, Martin P, Joiner C (2005) Reactivation of koi herpesvirus infections in common carp Cyprinus carpio. Dis Aquat Org 67: $15-23$

Uchii K, Telschow A, Minamoto T, Yamanaka H, Honjo MN, Matsui K, Kawabata Z (2010) Transmission dynamics of an emerging infectious disease in wildlife through host reproductive cycles. ISME J 2010:1-8

Walster CI (1999) Clinical observations of severe mortalities in koi carp, Cyprinus carpio with gill disease. Fish Vet J 3:54-58

Waltzek TB, Kelley GO, Stone DM, Way K and others (2005) Koi herpesvirus represents a third cyprinid herpesvirus (CyHV-3) in the family Herpesviridae. J Gen Virol 86: 1659-1667

Submitted: July 18, 2012; Accepted: March 26, 2013

Proofs received from author(s): June 28, 2013 